\title{
Quando a praça vira...: estudos de caso sobre a ocupação das praças na cidade do Rio de Janeiro
}

Ana Paula Menezes

Bruno Mendonça

Vera Tângari

\author{
RESUMO
}

0 presente artigo é parte integrante da pesquisa sobre a distribuição e classificação dos sistemas de espaços livres públicos e privados na cidade do Rio de Janeiro desenvolvida pelo Grupo SELRJ, vinculado ao Programa de Pós-Graduação em Arquitetura - PROARQ-FAU/UFRJ. Essa pesquisa apresenta o embasamento teórico e a metodologia para a classificação dos sistemas de espaços livres públicos e privados, pautados na pesquisa de caráter nacional da Rede QUAPÁ-SEL, liderada pela FAU-USP (MACEDO et al,. 2009; CAMPOS et al., 2011, 2012; TÂNGARI et al., 2012). 0 artigo em tela se debruça especificamente na análise do mapeamento e quantificação de um tipo específico de espaço livre público que são as praças e no processo de reversão desses espaços para implantação de escolas e clínicas de saúde na cidade do Rio de Janeiro, em especial nas Áreas de Planejamento AP3 e AP5, localizadas a norte e oeste da cidade, respectivamente. Para isso foi usado como ferramenta de mapeamento o programa de geoprocessamento ArcGIS, associado às informações fornecidas pela Prefeitura Municipal do Rio de Janeiro e seu banco de dados, que permitiram analisar os dados sobre praças na cidade e a incidência dos equipamentos públicos.

PALAVRAS-CHAVE: Espaços livres públicos; Praças; Praças ocupadas; Zona norte; Zona oeste; Rio de Janeiro.

\section{ABSTRACT}

This article is an integral part of the research on the distribution and classification of public and private open space systems in the city of Rio de Janeiro, developed by the SEL-RJ Group, linked to the Graduate Program in Architecture - PROARQ-FAU / UFRJ. This research presents the theoretical basis and methodology for the classification of public and private open space systems, based on the national research held by QUAPÁ-SEL Network, led by FAU-USP (MACEDO et al., 2009; CAMPOS et al., 2011, 2012; TANGARI et al., 2012). The article focuses specifically on the analysis of mapping and quantification of a specific type of public space, the squares, and on the process of reversion of these spaces for the construction of schools and health clinics in the city of Rio de Janeiro, especially in the Planning Areas AP3 and AP5, located to the north and west of the city, respectively. For this purpose, the ArcGIS geoprocessing program was used as a mapping tool, associated with the information provided by the Rio de Janeiro City Hall and its database, which allowed the analysis of the data on squares in the city and the incidence of public equipment.

KEYWORDS: Public spaces; squares; Occupied squares; North Zone; West Zone; Rio de Janeiro

\section{Introdução}

Analisar a importância dos espaços livres no processo de formação das cidades é uma tarefa bastante complexa, sendo o tema alvo de pesquisas por parte de diversos autores e grupos de estudo. Segundo Tângari (1999, p. 184), "ao se formar através da ação de agentes públicos e privados, a cidade conjuga espaços construídos e espaços livres de edificação [...] tanto os espaços construídos quanto os livres de edificação conferem caráter e qualificam a paisagem das cidades." 
Os espaços livres urbanos se destacam na paisagem da cidade e possuem extrema relação com a qualidade de vida e com a dinâmica de ocupação do território. Criam possibilidades para a vivência coletiva e se apresentam como o lugar onde as atividades e trocas sociais acontecem.

Apesar de exercer um papel de destaque, o espaço livre urbano vem sendo relegado ao tratamento de questões relacionadas à circulação de veículos e pedestres, o que compromete o caráter social dos mesmos, criando assim paisagens desprovidas de identidade (SILVA, 2004). No tocante ao projeto e à especialização dos espaços, Miranda Magnoli complementa ao afirmar que a excessiva especificidade funcional dos espaços livres, frequentemente atribuída de forma desnecessária, acaba por comprometer a criação de aberturas e espaços saudavelmente ambíguos que permitam uma criação ampla de significados (MAGNOLI, 1982).

Na cidade do Rio de Janeiro, de forma geral, em termos de dimensão e quantidade, os mais representativos espaços livres públicos estão relacionados a: circulação, formados por ruas e avenidas; proteção ambiental, em sua maioria sem acesso ao público ou de acesso restrito e onde ocorre a ocupação irregular de favelas e loteamentos informais; áreas de uso especial ou dominial cedidos às forças militares ou concessionárias de serviços (iluminação, abastecimento de água, transporte ferroviário, etc). A partir da quantificação realizada pelo Grupo SELRJ em 2017, foi possível, realizar uma análise comparativa entre as Áreas de Planejamento da Cidade, indicada no Quadro 01 conforme Mapa 01.

\section{Mapa 1: Limites do Macrozoneamento e Áreas de Planejamento}

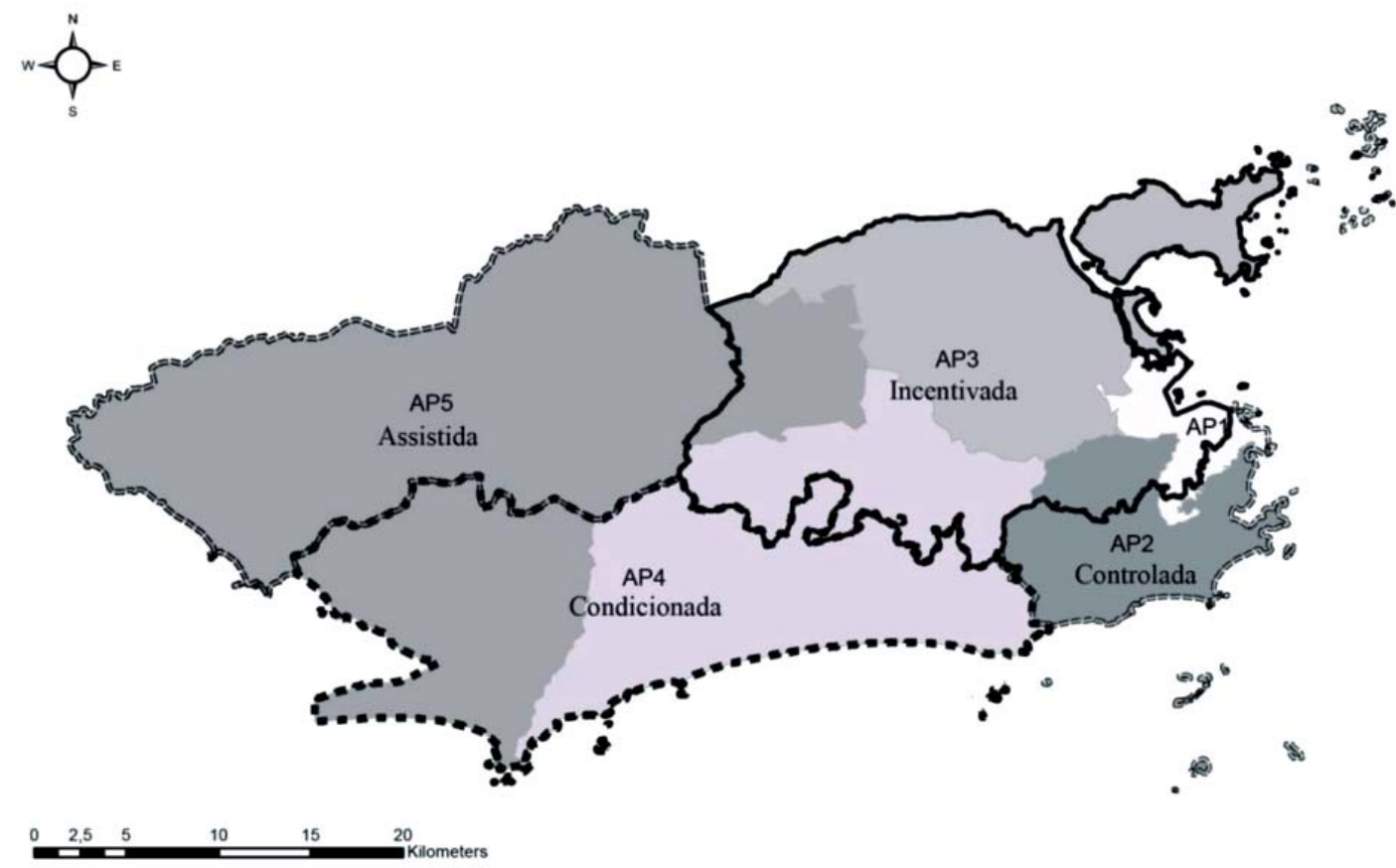

Fonte: Mapa adaptado por Bruno Mendonça, sobre base obtida em www.pcrj.rj. gov.br , 2017

Nesses dados, é possível observar que a Área de Planejamento 3 - AP3 é a área que apresenta o menor índice de espaços livres públicos por extensão territorial (36\%). Ao mesmo tempo, de modo inverso, é a região que concentra mais população, apresentado a maior densidade demográfica (119 hab/ha), conforme apresentado no Quadro 02. 
Quadro 01: Percentual de Espaços Livres Públicos por Área de Planejamento.

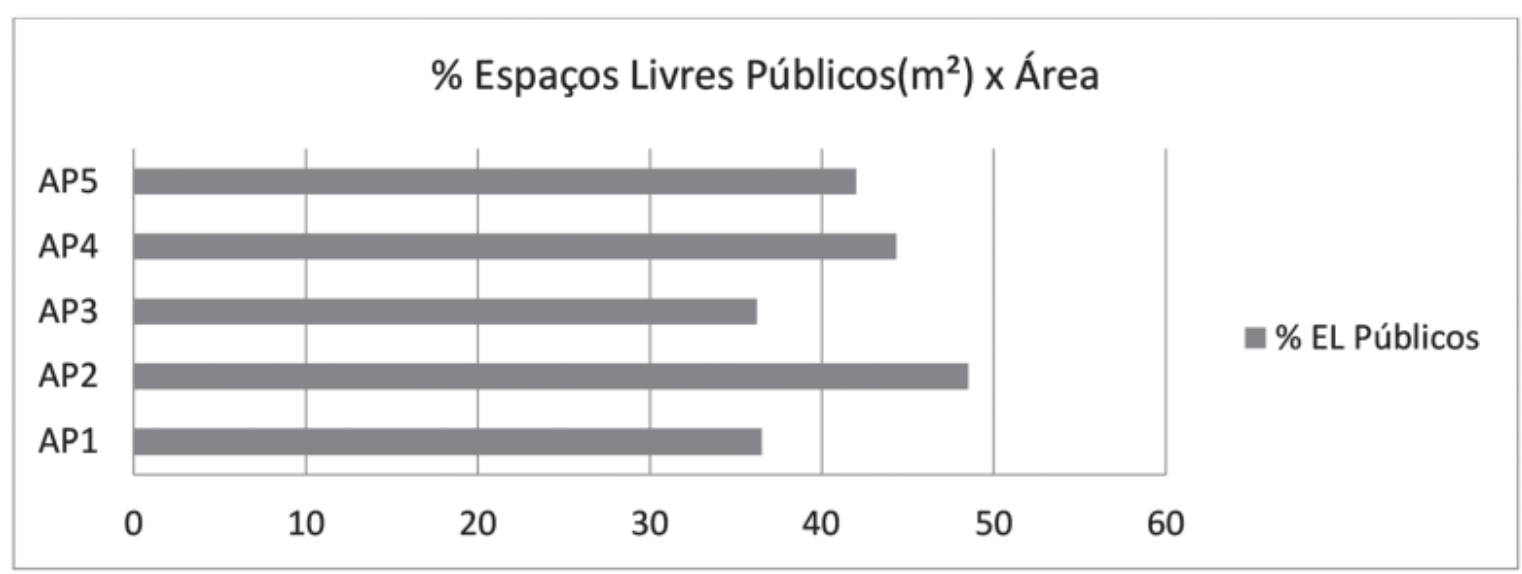

Fonte: SEL-RJ, 2017

Quadro 02: Percentual de domicílios, população e densidade demográfica por área de planejamento.

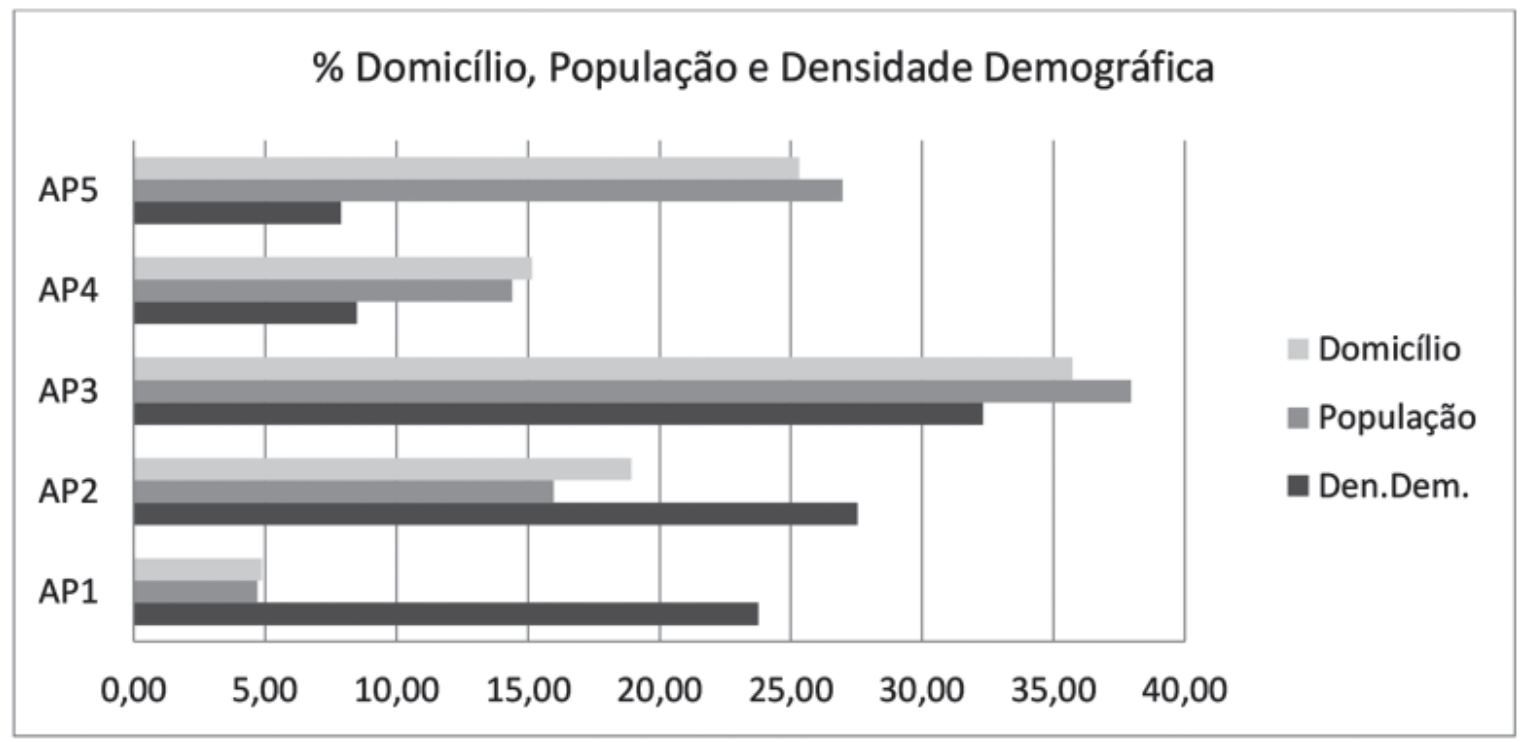

Fonte: IBGE, 2011. Gráfico elaborado pelo autor, 2017.

Tendo como foco o tipo específico de espaços livres públicos que são as praças, a classificação aplicada pelo Grupo Sistemas de Espaços Livres no Rio de JaneiroSEL-RJ a "praças", "praças não implantadas" e "praças ocupadas" é definida como (TÂNGARI, 2017): praças são áreas determinadas em projetos de loteamento, cumprindo a porcentagem determinada destinada a espaços livres públicos para atividades recreativas e lazer. Já as praças não implantadas são as mesmas definidas pela legislação que regulamente os loteamentos e destinadas a espaços livres de lazer e recreação, mas que não foram executadas. Por fim, as praças ocupadas são ainda as áreas do loteamento destinadas às praças, que foram ocupadas com a construção de equipamentos públicos de saúde, educação ou similares.

Nesse contexto, as praças, sob a perspectiva ambiental, são vistas como espaço público fundamental para a qualidade de vida e da paisagem urbana. São também percebidas como lugares onde as relações sociais são firmadas, além de reforçarem os aspetos da identidade cultural e da memória. Destacam-se na paisagem da cidade e possuem extrema relação com a qualidade de vida e com a dinâmica de ocupação 
do território, criando possibilidades para a vivência coletiva sendo, portanto, o lugar onde as atividades e trocas sociais acontecem. De acordo com Souza (2015), são substratos físicos materiais onde se consolidam as relações imateriais de vizinhança e de pertencimento e onde se encontram parte expressiva do patrimônio cultural de uma cidade ou de um bairro.

No sentido contrário ao processo de valorização e manutenção desse espaço público, em algumas regiões da cidade do Rio de Janeiro, em sua grande maioria em áreas periféricas e mais pobres, principalmente nas zonas norte e oeste (AP3 e AP5), os já escassos espaços públicos caracterizados por praças foram e estão sendo suprimidos para a implantação de escolas, na década de 1960, e de clínicas de família, na década de 2010.

A prática de tomar partido de espaço livre público destinado ao lazer para a implantação de outros serviços essenciais não é recente. Em 1960, na eleição da primeira gestão do recém-criado Estado da Guanabara, Carlos Lacerda promoveu sua candidatura com a promessa de acabar com o déficit de vagas nas escolas primárias do Estado. Até o fim deste mesmo ano, 78 escolas foram inauguradas e muitas delas se localizaram na região dos subúrbios do Rio de Janeiro. Entre os anos de 1960 e 1965 cerca de 200 escolas primárias foram construídas (PEREZ, 2005). Duas importantes premissas foram então adotadas pelo então governo estadual para agilizar o processo de construção das escolas e reduzir os custos de implantação: a primeira estabeleceu um padrão arquitetônico baseado na padronização do projeto e dos materiais utilizados e a segunda foi a implantação dos edifícios em área desafetada ${ }^{1}$ de praças públicas, segundo exemplo da Figura 1.

\section{Figura 1: Escola instalada em praça no bairro de Osvaldo Cruz}

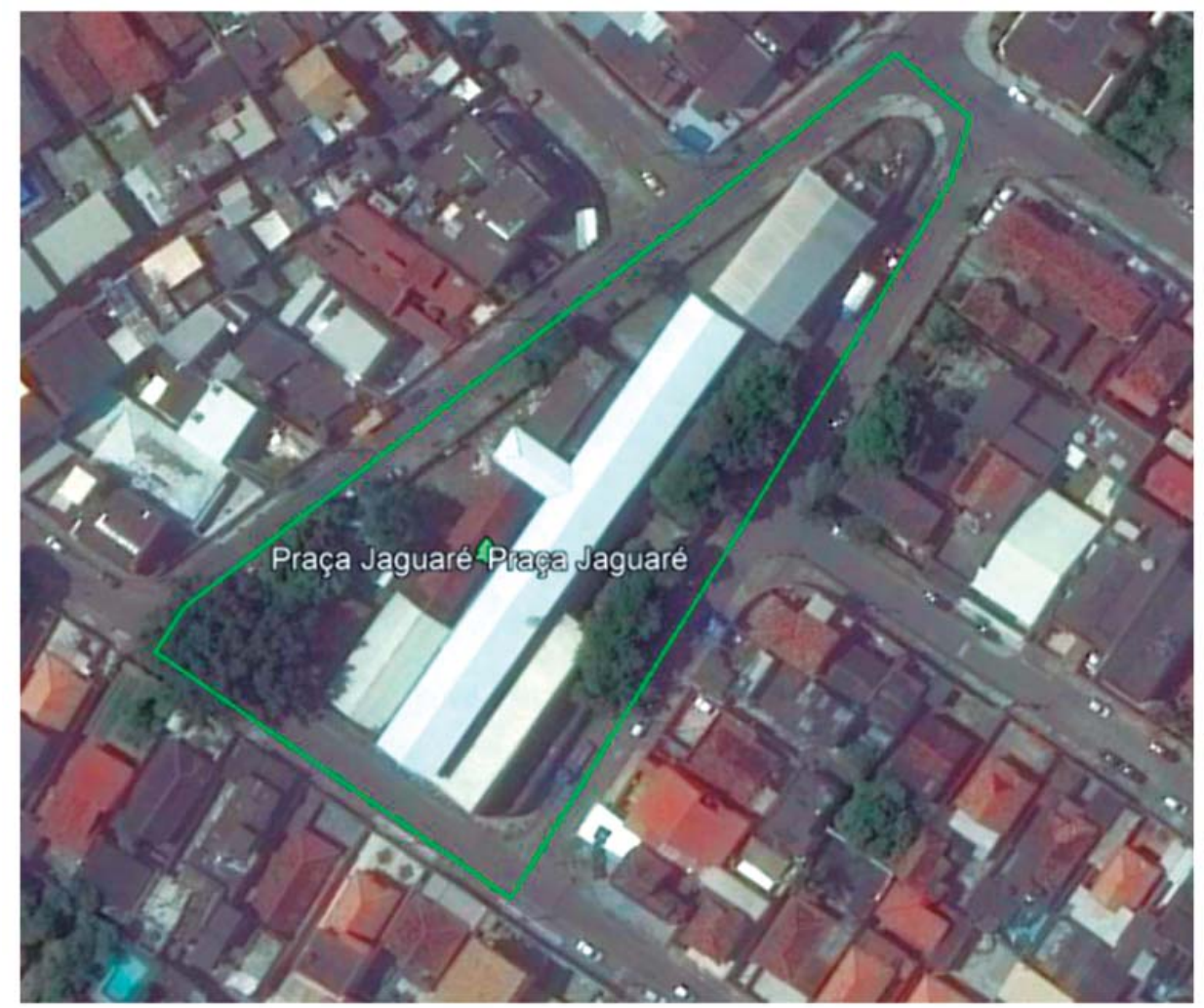

Fonte: Google Earth, 2017.

1 Desafetação é o processo de transformação do bem de uso comum ou de uso especial em bem público dominical, promovido mediante lei específica. 


\section{A praça como direito à paisagem e ao lazer}

Que direito constitucional é mais importante? Existe um mais importante que o outro? Podemos abrir mão de um deles para proporcionar um outro? Como encarar o fato do poder público se utilizar de prerrogativas jurídico-administrativas para construir uma escola (direito à educação) ou clínica (direito à saúde) em praça existente, reduzindo ou eliminando, em alguns casos, o direito ao lazer de uma comunidade ou até mesmo de um bairro?

Segundo o Estatuto da Cidade, o direito de propriedade privada ou o uso de um bem público devem estar condicionados à sua função social, e, nesse caso, a destinação do bem público - no caso da praça - foi desviada de função através do instrumento jurídico "Alteração de Afetação". Quando falamos sobre a função social da propriedade pública há um grande conflito de entendimentos. Segundo Bobbio (2006):

Considerando que os bens públicos já são naturalmente vocacionados ao atendimento das necessidades da sociedade e da coletividade como um todo, surge a dúvida de como conciliar a característica natural dos bens públicos com a aplicação da função social. Para isso, será importante verificar onde se encaixa a função social da propriedade pública quanto à justiça, validade e eficácia.

Urge compreender até onde a prática de Alteração de Afetação do bem público afeta positiva ou negativamente a cidade, e se esse instrumento jurídico precisa ter seus efeitos estudados mais a fundo antes que o ente público faça uso do mesmo para alterar a função e a qualidade sócio ambiental da paisagem (Figura 2). Dworkin (2007) fornece um conceito de princípio que ratifica o enquadramento da função social como tal.

É interessante perceber como o administrador público atropela suas próprias leis. $\mathrm{Na}$ Lei Orgânica do Município do Rio de Janeiro (PCRJ, 2010):

Art. 235 - As áreas verdes, praças, parques, jardins e unidades de conservação são patrimônio público inalienável, sendo proibida sua concessão ou cessão, bem como qualquer atividade ou empreendimento público ou privado que danifique ou altere suas características originais.

Figura 2 - Morador utilizando o equipamento da praça Lealdina Muniz em maio de 2017.

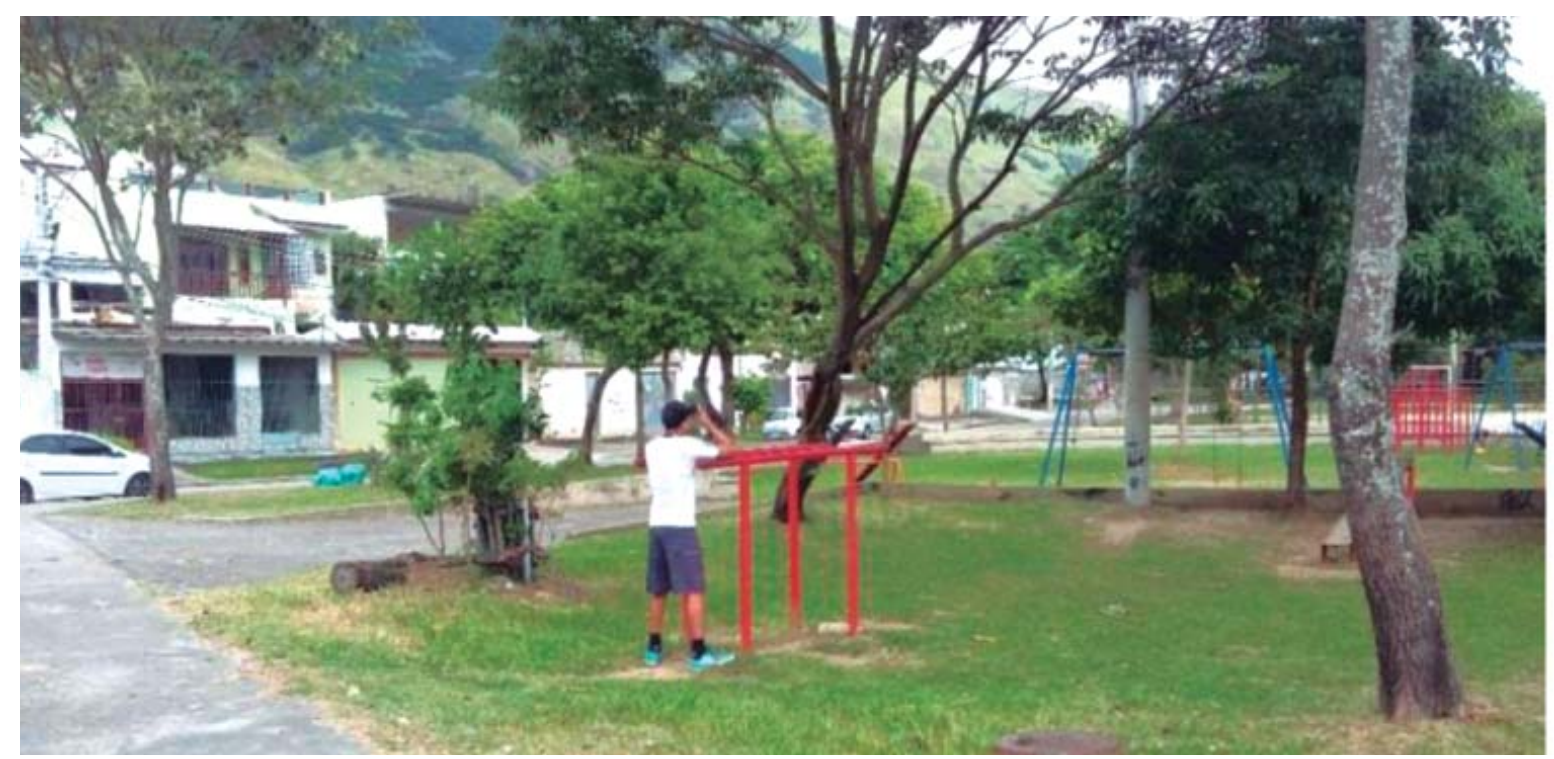

Foto: Ana Paula Menezes, 2017 
Desde 2013, o então prefeito Eduardo Paes vinha alterando artigos da Lei Orgânica do Município do Rio de Janeiro de modo a facilitar a construção das Clínicas da Família. Um exemplo disso é o Decreto $\mathrm{N}^{\circ} 38139$ de 3 de dezembro de 2013 que altera o uso de bem comum para "uso especial" destinado a unidade básica de saúde, sem qualquer discussão prévia com moradores da região, mas "considerando que a alteração da afetação não importará em desvirtuamento da finalidade pública da área" e "considerando o interesse público".

Art. $1^{\circ}$. Fica parcialmente alterado de bem de uso comum, integrante do bem público, designado Praça Eduardo Vilaça, em sua parcialidade, situada na Rua Paulo Vidal e Rua Henrique Basílio, em Realengo, figurada no Projeto Aprovado de Alinhamento (PAA) n ${ }^{\circ} 9528$ e no Projeto Aprovado de Loteamento (PAL) $n^{\circ} 32574$, na sua parte situada entre as Ruas Antônio Simões Martins e a Rua Henrique Basílio, consistindo de 1.910,35 m², passando a ser bem de uso especial destinado a Unidade Básica de Saúde.

Tomando como premissa as palavras de Dworkin (2007) compreende-se que a função social tenha um sentido moral, pois o proprietário tem responsabilidade sobre a destinação da propriedade e sendo essa de natureza pública essa responsabilidade extrapola os limites físicos da propriedade em si. Quando o proprietário não faz bom uso de sua propriedade causando impactos negativos ao seu redor essa responsabilidade deveria ser maior quando o poder público é responsável direto por sua gestão.

Segundo Filho e Pereira (2016), “os bens de uso especial são bens voltados a aparelharo serviço público, isto é, são aqueles aplicados no desempenho das atividades estatais. Visam à execução de serviços públicos. São imóveis indispensáveis à prestação e funcionamento do serviço administrativo e ao serviço público em geral". No entanto a falta de cuidado na inserção de uma edificação em uma área cuja destinação era um espaço livre público, conforme ilustram as Figuras $\mathbf{3 a}$ e $\mathbf{3 b}$, envolve muita mais do que simplesmente a troca de função social, mesmo com a finalidade de continuar prestando serviços destinados à população em geral.

Figuras 3a e 3b - Área da praça após a implantação da Clínica da Família em Realengo
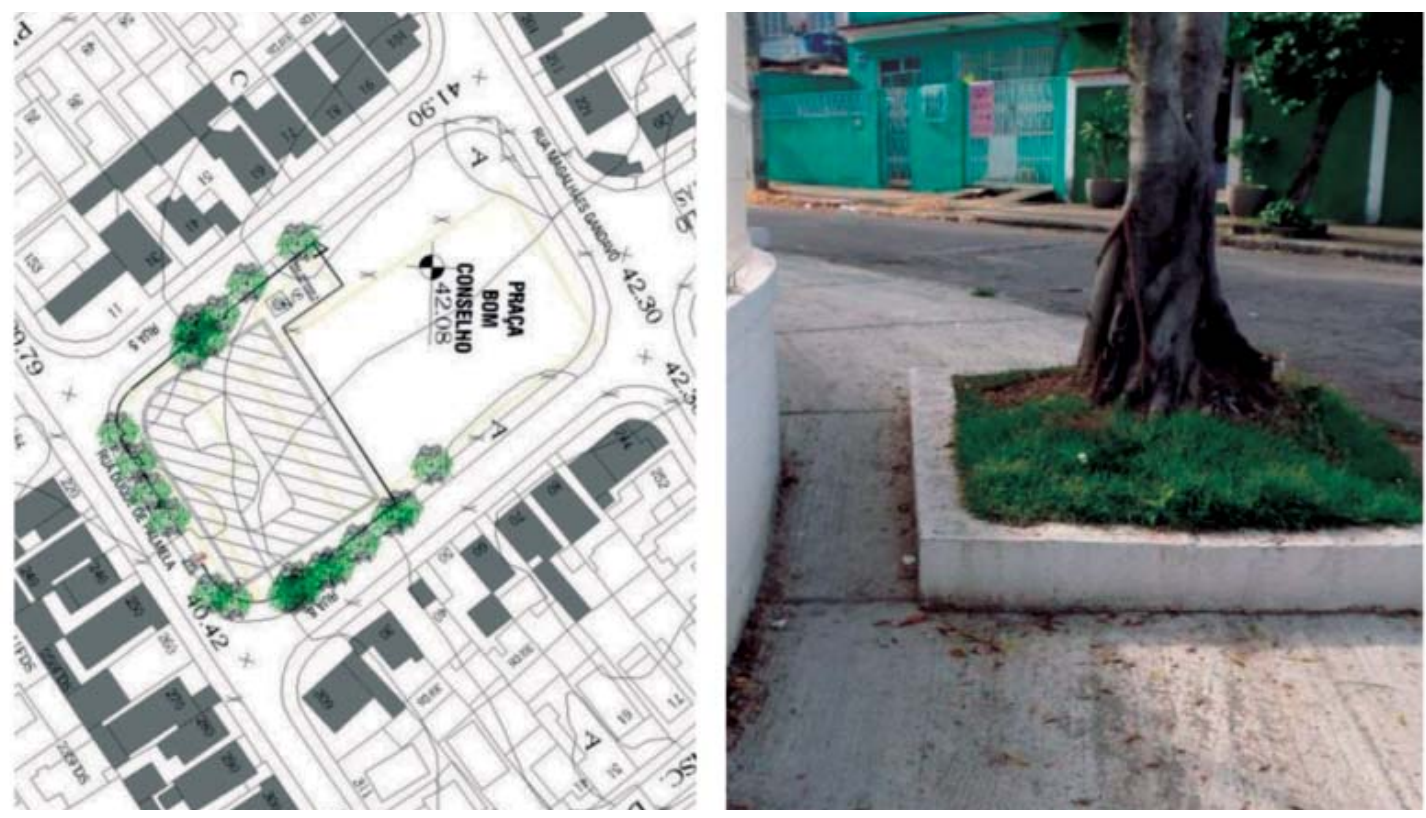

Planta por Ana Paula Menezes a partir de planta cadastral da Prefeitura da Cidade do Rio de Janeiro, 2017; foto de Ana Paula Menezes, 2017 
No entendimento dos autores acima citados: "A análise da Função Social leva a certeza de que se trata de um princípio de direito fundamental e que por isso deve ser aplicado do modo mais dilatado, pois não será excluído em caso de conflito com outros princípios, mas sim terá sua aplicação ponderada, sopesada para harmonização do sistema constitucional". Os autores, no entanto, não deixam claras as questões relativas aos bens dominicais, particularmente as praças - quando essas são ocupadas e perdem completamente sua função social que daria direito ao lazer.

Devemos também abordar outros instrumentos jurídicos dentro do campo do urbanismo tais como o Estudo de Impacto Ambiental (E.I.A.) e o Estudo de Impacto de Vizinhança (E.I.V.). Esses instrumentos são importantes para que efeitos negativos das medidas de desafetação sejam mitigados, ainda no estudo inicial dos projetos. Entretanto, conforme verificado nas praças ocupadas apresentadas adiante, não foram sequer cogitados. Não obstante a dimensão não ser elegível para a obrigatoriedade de apresentação de um E.I.V., a natureza da desafetação e da ocupação frente à origem da destinação do espaço livre público deveria ser uma exigência, já que o E.I.V. é executado de forma a contemplar a análise dos efeitos positivos e negativos do empreendimento ou atividade na qualidade de vida da população residente em suas proximidades.

\section{Direitos afetados}

No caso das Clínicas da Família implantadas pela Prefeitura da Cidade do Rio de Janeiro, muitas vezes as praças eram o único espaço livre público com vegetação de um bairro ou setor de bairro para construção do equipamento público com a função social destinada à saúde dos cidadãos. Na implantação, muitas árvores foram retiradas alterando significativamente o micro-clima dos lugares onde as clínicas foram construídas. Segundo Wolch et al. (2014): "A acessibilidade desigual do espaço verde urbano tornou-se reconhecida como uma questão de justiça ambiental, uma vez que a conscientização de sua importância para a saúde pública tem se tornado

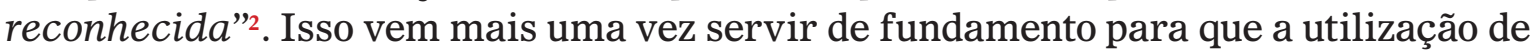
espaços destinados ao lazer tenha uma seleção mais criteriosa evitando dessa forma cercear um direito em razão de outros.

A questão do Direito à Paisagem muitas vezes nem é levada em consideração, pois as consequências da perda desse direito não são mensuráveis sob o ponto de vista da materialidade, ficando restrito ao âmbito do valor, do significado ou da memória para determinada comunidade. No caso da ocupação das praças por equipamentos públicos, muitas vezes desprovidos de qualquer preocupação estética e de adequação com o ambiente ao qual se inserem, esses causam impactos irreversíveis àquela comunidade. A edificação indiscriminada, a poluição visual dos espaços públicos ou a ocupação indevida do espaço coletivo podem descaracterizar ou até mesmo fazer desaparecer da paisagem urbana algum referencial peculiar.

\subsection{Considerações sobre o direito ao lazer e à paisagem}

Da necessidade de organizar o espaço habitável, o campo do o Direito Urbanístico foi moldado a fim de legitimar as intervenções do Poder Público na propriedade e na cidade, com o objetivo de garantir a supremacia do

2 Tradução nossa - no original: The uneven accessibility of urban greenspace has become recognized as an environmental justice issue as awareness of its importance to public health has become recognized. 
interesse coletivo. No entanto, percebe-se cada vez mais desprezo pelo amplo alcance do direito quando o mesmo entra em conflito com interesses políticos. Sendo o Direito Urbanístico diretamente ligado ao Direito de Propriedade, quando a ação jurídica se refere uma propriedade pública urge estabelecer critérios mais rígidos para a utilização desses espaços que, por serem de caráter coletivo, demandam que sua utilização deva ser debatida e definida em conjunto com a sociedade.

No que tange aos Direitos Sociais, a ocupação das praças por clínicas feriu dois princípios. O Direito ao Lazer foi ignorado em uma das praças estudadas, e pelo fato de que essa inserção de equipamento público não ter sido precedida por um Estudo de Impacto de Vizinhança, o Direito à Acessibilidade foi completamente prejudicado em algumas áreas.

Com relação aos princípios urbanísticos fica clara que a questão da Função Social da Propriedade Pública carece de instrumentos que moralizem suas atribuições, pois quando a mesma não alcança sua função atinge também a Função Pública do Urbanismo, já que o primeiro princípio é de que o urbanismo é uma função pública. Ressalta-se que o direito urbanístico como instrumento normativo, através do qual o poder público deveria ordenar a realidade no interesse coletivo, deveria atuar como condutor da atividade urbanística, o que muitas das vezes foi sobrepujado por interesses políticos em diversos momentos da história da cidade. Nesse sentido, por ser tratar de um bem público a utilização indiscriminada da "Alteração de Afetação" alterou significativamente a paisagem causando mudanças na mesma e ferindo o Direito à Paisagem. Desprezar o uso de instrumentos jurídicos dentro do campo do urbanismo, tais como o Estudo de Impacto de Vizinhança, pode trazer consequências que só futuramente serão sentidas.

Diante desse contexto, torna-se imperativa a melhor proteção à paisagem urbana, não só consonante com as questões ambientais, mas também no sentido de prover o cidadão de lugares adequados à prática do lazer e das relações sociais.

\section{Resultados empíricos}

Os estudos de caso a seguir apresentados referem-se às dissertações de mestrado em andamento de Bruno Ragi Mendonça (Mestrado Acadêmico em Arquitetura- PROARQ/UFRJ) e de Ana Paula Menezes (Mestrado Profissional em Arquitetura Paisagística/PROURB-UFRJ), com términos previstos em 2018. Distinguem-se em contextos e escalas de análise e objetivos específicos, mas tem um foco comum: a condição de praças na cidade do Rio de Janeiro nas Áreas de Planejamento 3 e 5. Os estudos de caso seguem apresentados.

\subsection{Estudo de caso na Área de Planejamento 3}

Com base no histórico de supressão de espaços livres públicos, a pesquisa buscou realizar a compatibilização das áreas de praças e parques nas Áreas de Planejamento da cidade, assim como suas condições atuais, a partir do levantamento realizado pela Prefeitura da Cidade do Rio de Janeiro $^{3}$, quanto à demarcação desses espaços. 
Limitou-se o recorte de análise aos bairros que apresentam características de uma ocupação mais consolidada e que são atravessados pela Estrada de Ferro Central do Brasil, inclusos no limite geográfico da Área de Planejamento 3 (AP3), conforme ilustrado no Mapa 02. A AP3 corresponde a $16,6 \%$ do território municipal, possuindo os maiores índices de concentração de população, domicílios e densidade demográfica em comparação com as demais áreas da cidade, segundo dados constantes no Quadro 2, anteriormente apresentado. Segundo os dados do censo realizado em 2010, a região da AP3 concentrava 2.440.118 habitantes (38\%), distribuídos em 8.608,31 domicílios (36\%).

A AP3 é atualmente subdividida em 13 Regiões Administrativas (R.A.), constantes no Mapa 03, que são conjuntos de bairros vizinhos agrupados por suas semelhanças em relação a características morfológicas e socioambientais: ${ }^{5}$ Anchieta, Complexo do Alemão, Ilha do Governador, Inhaúma, Irajá, Jacarezinho, Madureira, Maré, Méier, Pavuna, Penha, Ramos e Vigário Geral. Nesse contexto, o recorte de análise destacado para a pesquisa, formado pelas Regiões Administrativas do Méier e Madureira, subdivide-se em 16 bairros, atravessados por aproximadamente $17 \mathrm{~km}$ da linha férrea Central do Brasil, que nesse trecho possui 14 estações ferroviárias.

\section{Mapa 02: Bairros analisados na AP3.}

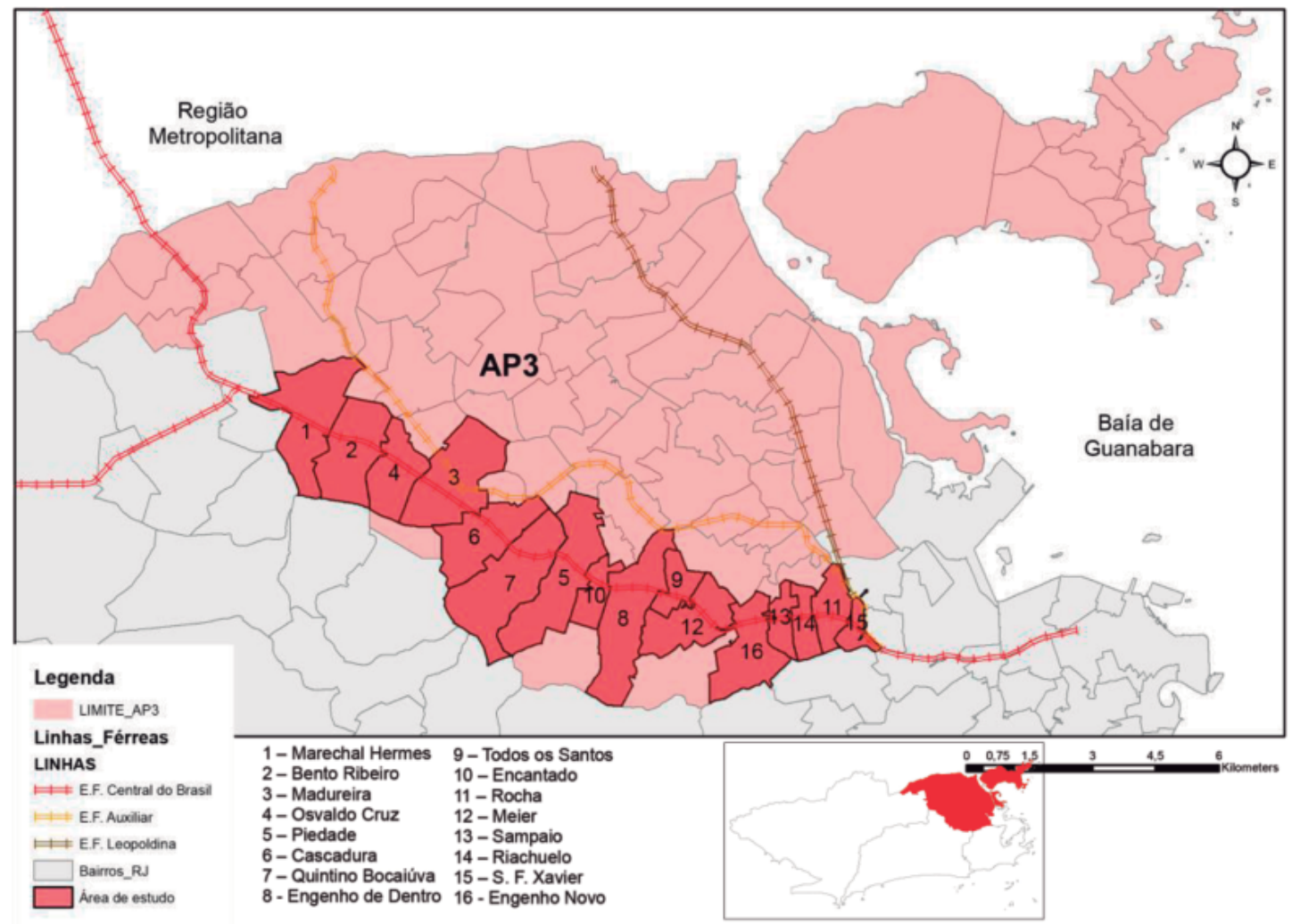

Fonte: Mapa elaborado por Bruno Mendonça sobre base do Portal GeoRio, 2017.

4 https://censo2010.ibge.gov.br/sinopse/index.php?uf=33.

5 Cabe destacar que a Região Administrativa é a unidade de análise adotada pelo Grupo SELRJ para sistematizar o mapeamento e dados analíticos das pesquisas que desenvolve para a Cidade do Rio de Janeiro. 
De acordo com a pesquisa em andamento, os dados indicaram que dentre as 114 praças identificadas em recorte específico de estudo, apenas 58 (51\%) delas foram identificadas e podem ser de fato caracterizadas como praças ou parques. Do restante, $13(12 \%)$ são decretadas como praça segundo o levantamento, porém através da desafetação parcial ou total do espaço público, são ocupadas, em sua maioria por escolas ou clínicas públicas. Já as 43 (37\%) restantes são áreas indicadas como sendo praças, porém são na realidade espaços livres privatizados (apropriação indevida do espaço público), ou áreas livres que deixaram de existir por mudanças viárias em geral. O levantamento realizado deu origem ao Mapa 4 e o Quadro 03 que elucidam as informações prestadas.

\section{Mapa 03: Regiões administrativas da AP3.}

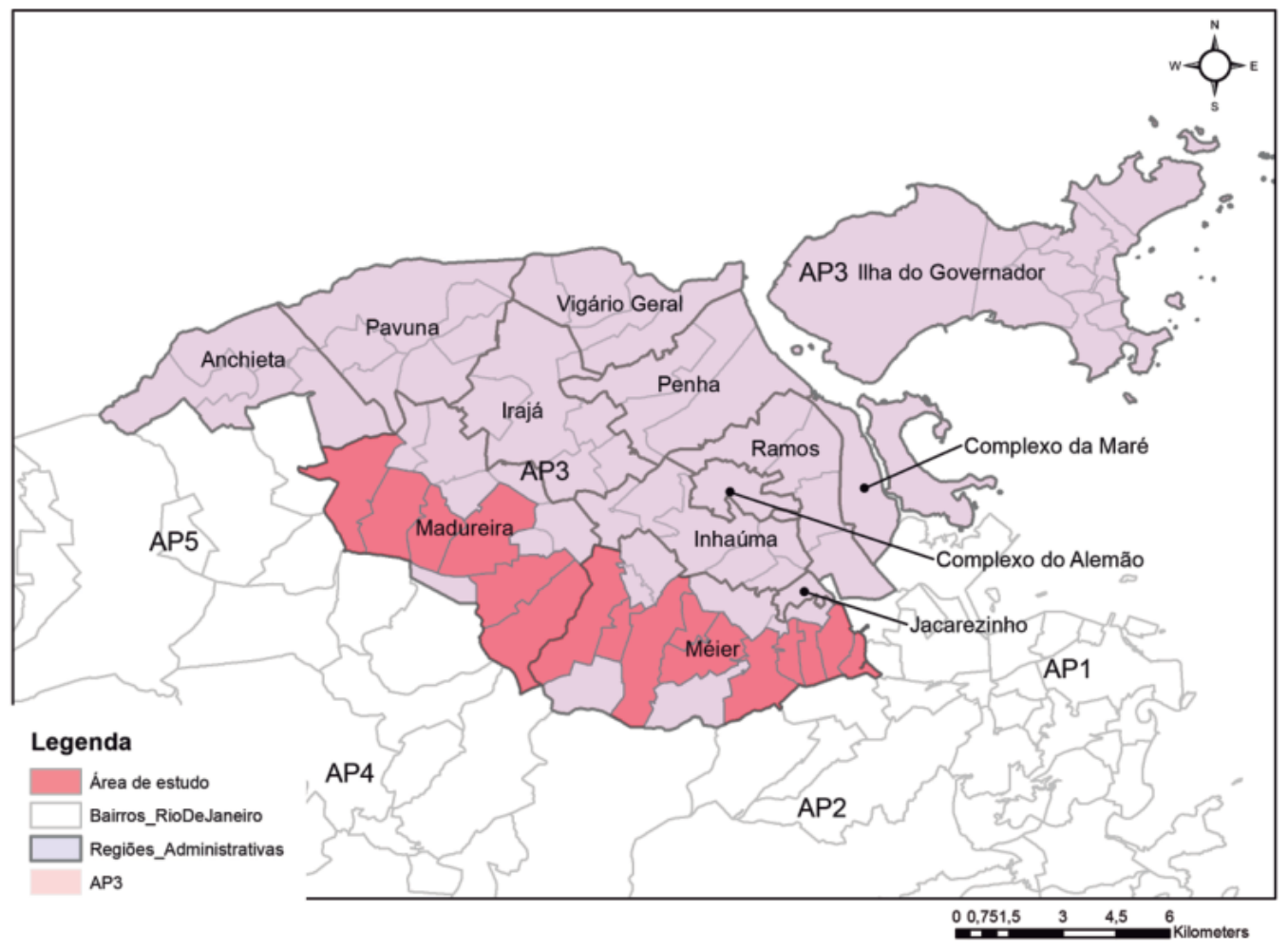

Fonte: Mapa elaborado por Bruno Mendonça sobre base do Portal GeoRio, 2017.

Segundo os dados coletados e mapeados, Madureira e Marechal Hermes se destacam sendo os bairros com o maior número de praças existentes. Marechal Hermes e Engenho de Dentro apresentam os maiores números de praças inexistentes. No primeiro, muitos espaços demarcados como praças são na realidade canteiros e estacionamentos pertencentes a condomínios residenciais. Já no bairro do Engenho de Dentro, as áreas demarcadas ao norte da ferrovia, são atualmente terrenos ocupados por prédios residenciais, e ao sul as áreas demarcadas incorretamente são grandes áreas ocupadas por habitações informais nas franjas do Maciço da Tijuca. Marechal Hermes ainda se destaca pelo número de praças ocupadas juntamente com o bairro de Osvaldo Cruz. Os bairros do Riachuelo e Sampaio não possuem nenhum espaço público de lazer representado por praças. Nesses casos, a praça entendida por Queiroga enquanto patrimônio público, espaço de ação e troca social, elemento urbano ícone do lugar perde seu significado (QUEIROGA, 2001). 
O jogo do poder e das negociações da gestão pública em diferentes tempos e o não aprofundamento jurídico sobre o campo do urbanismo e suas reais necessidades acabam por permitir a abertura de brechas, conforme discutido anteriormente, que possibilitam a administração municipal utilizar-se de decretos e dessa forma suplantar as diretrizes urbanísticas contidas no Plano Diretor, que são capazes de zelar pela preservação do espaço público.

Dessa forma a maioria da população que não tem alternativa senão aceitar as imposições acaba por achar em outros espaços a possibilidade do seu lazer. "Reverte os significados dos espaços que lhe são impingidos. Cria, às vezes com muita dificuldade e desgaste, ordens próprias que ultrapassem as ordens simplistas e abstratas dos planejadores" (SANTOS; VOGEL, 1981, p.12).

Mapa 4: Localização e análise de praças e parques - recorte na APe.

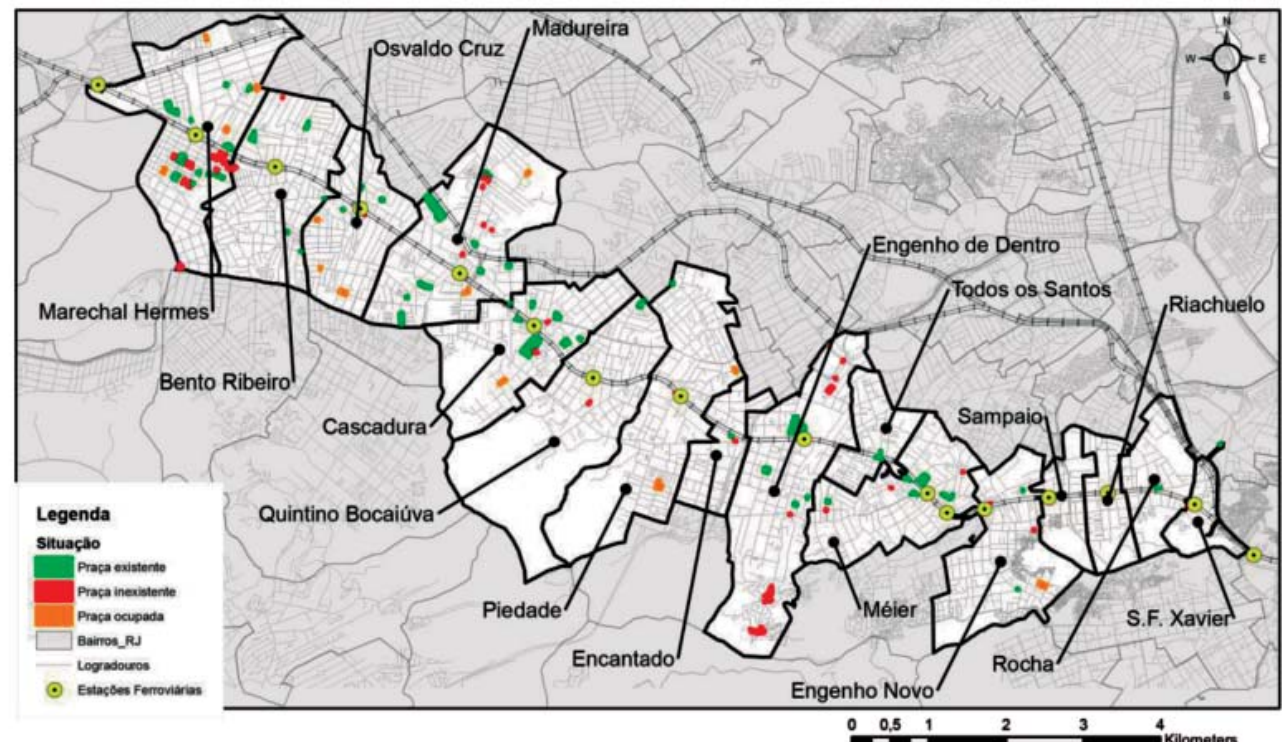

Fonte: Mapa elaborado por Bruno R. Mendonça, sobre base do Portal GeoRio, 2017.

Quadro 3: Situação de praças e parques por bairro.

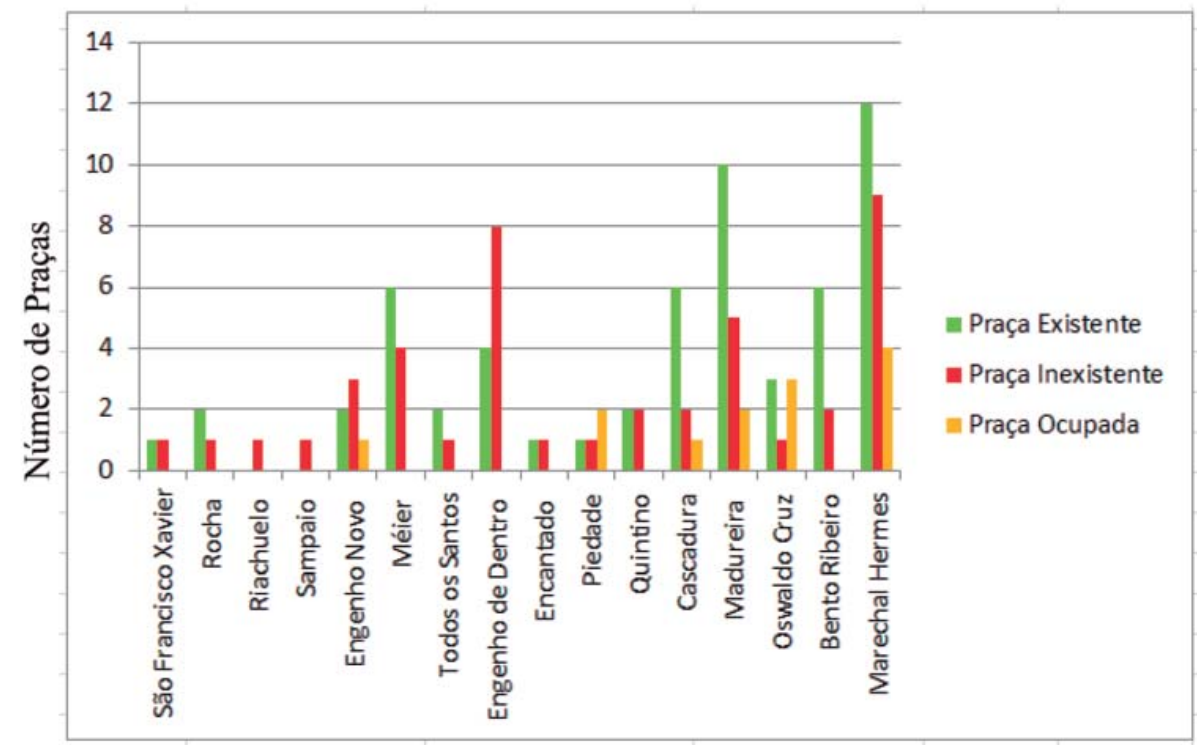




\subsection{Estudo de caso na Área de Planejamento 5}

Enquanto as praças do centro e zona sul vicejam qualidade ambiental e manutenção, as praças da zona oeste, sobretudo na Área de Planejamento 5 , sofrem de carência de projetos que promovam elementos carregados de significados para seus moradores. Nesse contexto, cabe esse debate, pois, com tantas mazelas principalmente em saúde e educação, por que se preocupar com a ocupação de praças por equipamentos tão importantes para os cidadãos cariocas? A questão que fica: "por que na praça"? A qualidade de vida urbana passa ao longo da vivência nas praças e muitas vezes essa não apropriação das praças pelos moradores se deve à falha ou falta de projetos e a negociações no plano político-administrativo.

Os estudos de caso da pesquisa na AP5 estão localizados nos bairros mais quentes do município do Rio de Janeiro. Bangu, Campo Grande e Realengo são conhecidos pelas altas temperaturas, devido à localização entre os maciços da Pedra Branca e Gericinó, onde Bangu é um bairro conhecido pelas máximas registradas durante o verão carioca. Nesse contexto, o tratamento dedicado pelo poder público às praças muitas vezes não leva em consideração as temperaturas elevadas da região e com isso esses espaços só são ocupados quando o sol perde a força, do poente em diante. Projetos inadequados contribuem para esse afastamento e com isso abrem-se brechas para a ocupação desses espaços livres públicos por equipamentos de educação ou saúde, que poderiam ser implementados nos locais previamente destinados segundo a legislação federal.

Nos últimos anos de governo do então prefeito Eduardo Paes, cuja gestão se encerrou em 2016, foram lançadas licitações a fim de construir mais 40 Clínicas da Família no município, sendo 28 delas na zona oeste, especificamente nas Áreas de Planejamento 4 e 5. Desse total, 14 seriam implantadas na AP5. Dentre as 14 áreas, 8 são atualmente situadas em praças, seja na totalidade de suas dimensões ou em pequenas ou grandes proporções. Da época do lançamento do edital até a efetivação do início das obras, alguns terrenos mudaram, sendo que das 8 praças apenas 1 em Paciência não era praça e sim um lote dentro de um hospital (Hospital Municipal Raphael de Paula e Souza em Curicica).

Os bairros na AP5 que tiveram suas praças ocupadas foram Bangu, Campo Grade, Cosmos, Paciência e Realengo. Campo Grande recebeu 5 Clínicas da Família nesse último lote, sendo 3 delas em praças. As duas clínicas de Realengo foram implantadas em praças. Os bairros de Bangu, Cosmos e Paciência receberam 1 clínica cada um. Chama a atenção o fato de que esses bairros tiveram suas ocupações realizadas de forma regular com loteamentos e que, por conta de atendimento à Lei de Parcelamento do Solo Urbano (BRASIL, 1979), destinaram-se parcelas de terra para uso público a ser definido pela administração municipal. Muitas vezes lotes já com destinação para edificar escolas e equipamentos de saúde foram preteridos, pois a utilização de espaços em praças prevaleceu.

A ocupação de praças passou a ser objeto de indagações por parte dos moradores de áreas adjacentes às mesmas. Algumas comunidades fortes conseguiram modificar essa ocupação. No site "Se a cidade fosse nossa", o designer e morador do Grajaú, Gustavo Bueno, faz um desabafo:

A cada ano a prefeitura avança sobre nossas áreas de convivência na cidade do Rio de Janeiro "propondo" construções de equipamentos públicos de forma um tanto impositiva e buscando gerar visibilidade para o governo 
e seus parceiros políticos locais. Em alguns casos, como na Praça Nobel, no Grajaú, Praça Marechal Maurício Cardoso, em Olaria, Parque José Orlando Bernardes, em Vista Alegre e na Praça Waldemar Teixeira, em Pedra de Guaratiba, existe ou existiu mobilização e contestação por parte de moradores locais e com isso, algumas vitórias. Entretanto, na maioria das vezes, se vende à população - com apoio da mídia de massa, um sonho de saúde e educação, administrado por organizações sociais (OS). Muitas vezes, simplesmente nem se escuta a população. E isso vai de encontro à Lei Orgânica do Município do Rio de Janeiro que veda qualquer empreendimento ou atividade que danifique ou altere suas características originais.

O relato reflete o que encontramos nas conversas preliminares em campo onde alguns moradores se queixaram exatamente dessa falta de diálogo entre o poder público e a comunidade que ele se diz atender.

Dentre as 8 praças inicialmente listadas, foi feita a escolha das 4 praças objeto da pesquisa, apresentadas a seguir: Praças Lealdina Muniz, em Bangu; Pedro Veloso e Sangradouro, em Campo Grande; Marobá, em Realengo.

\section{a) Praça Lealdina Muniz - Bangu}

Dentre as praças analisadas, a Praça Lealdina Muniz, apresentada na Figura 4, é a que mais possui características predominantes como área de lazer comunitário e para todas as faixas etárias, gêneros e tipos de interesses. A edificação da Clínica da Família localiza-se à direita na praça.

\section{Figura 4: Implantação da Clínica de Bangu na Praça Lealdina Muniz}

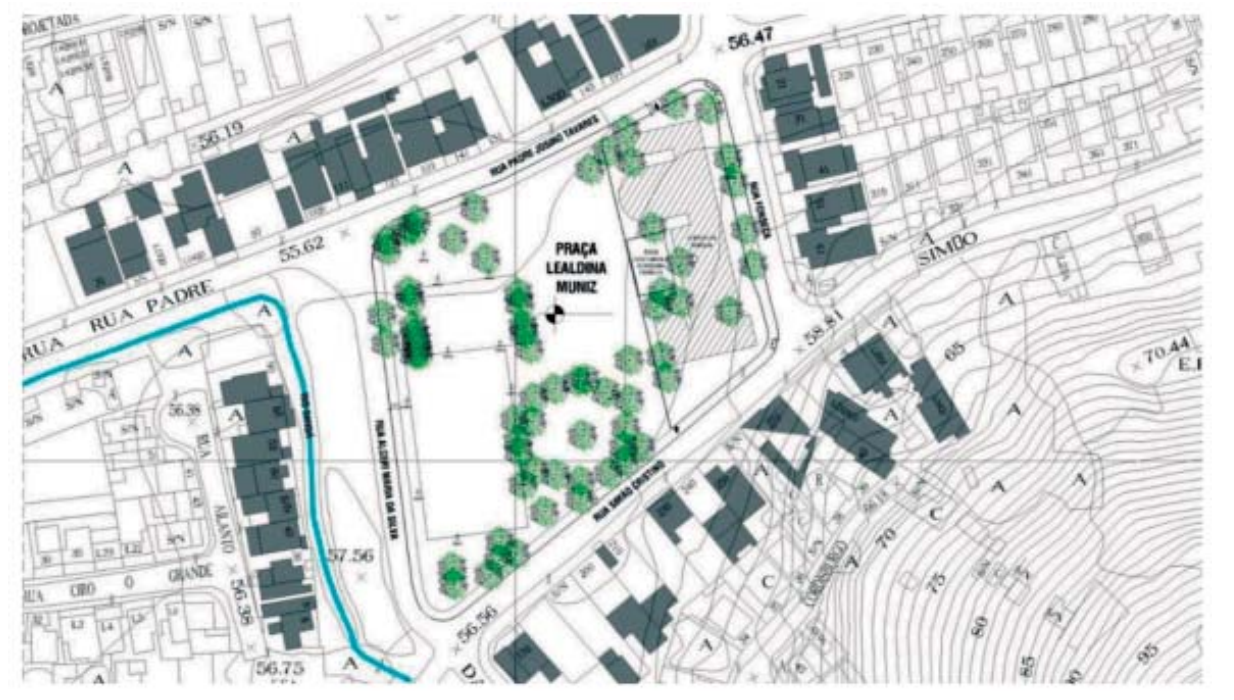

Fonte: Ana Paula Menezes sobre planta cadastral fornecida pela PCRJ, 2017

\section{b) Praça Pedro Veloso - Campo Grande}

Tem com características marcantes como área de lazer adequada a todas as faixas etárias e conta com áreas densamente arborizadas, 
equipamentos de lazer infantil, quadra poliesportiva, mesas e bancos. A clínica, ainda em fase de construção, ocupará um terço da área da praça no trecho superior, conforme demonstrado na Figura 5. Para implantação da clínica foi aproveitada uma área que era utilizada como campinho de futebol. Cabe destacar que essa obra está suspensa (Figura 5).

\section{c) Praça Sangradouro - Campo Grande}

Caso mais grave de ocupação pelo poder público de áreas destinadas ao lazer, a Praça Sangradouro deixou de existir conforme apresentado na Figura 6. Seus $2.574 \mathrm{~m}^{2}$ foram totalmente ocupados pela Clínica da Família que atualmente conta com amplos espaços ajardinados, porém cercados (Figura 6).

Figura 5: Implantação da Clínica de Campo Grande II na Praça Pedro Veloso

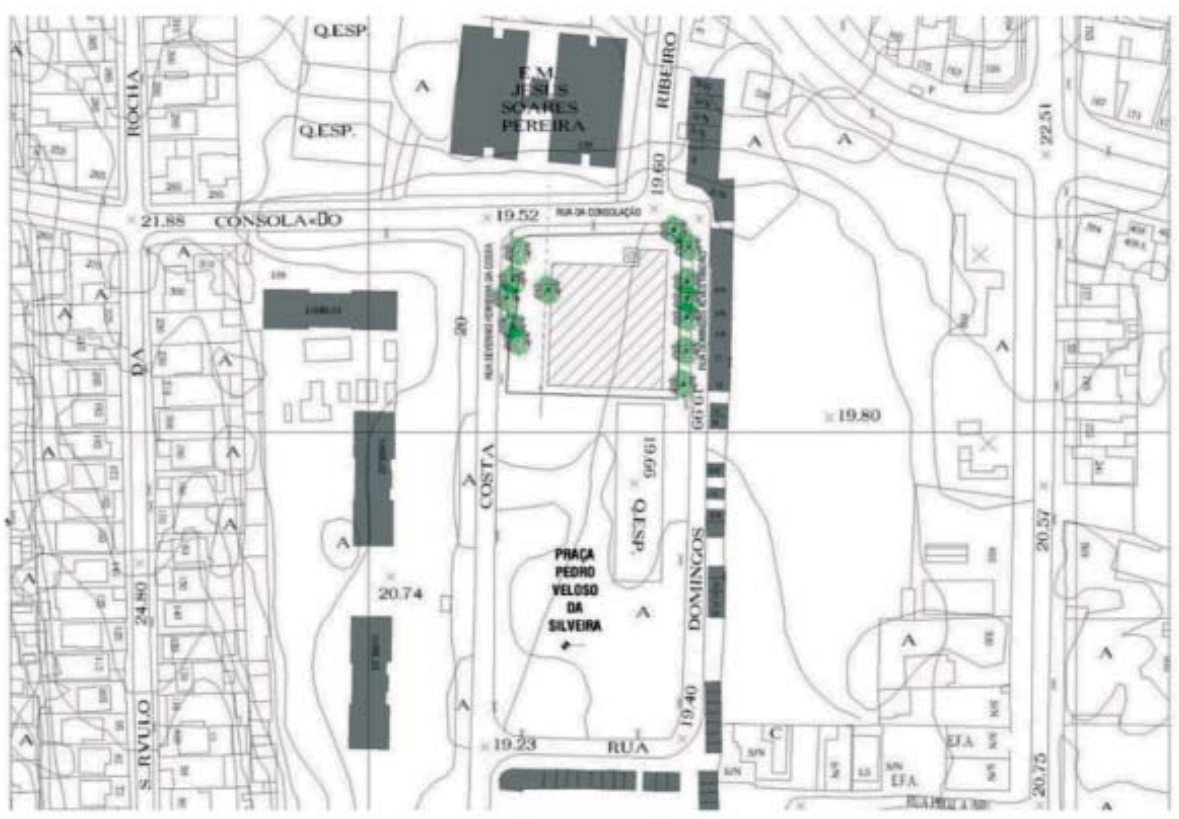

Fonte: Ana Paula Menezes sobre planta cadastral fornecida pela PCRJ, 2017

Figura 6: Implantação da Clínica Arthur Zanetti na Praça Sangradouro

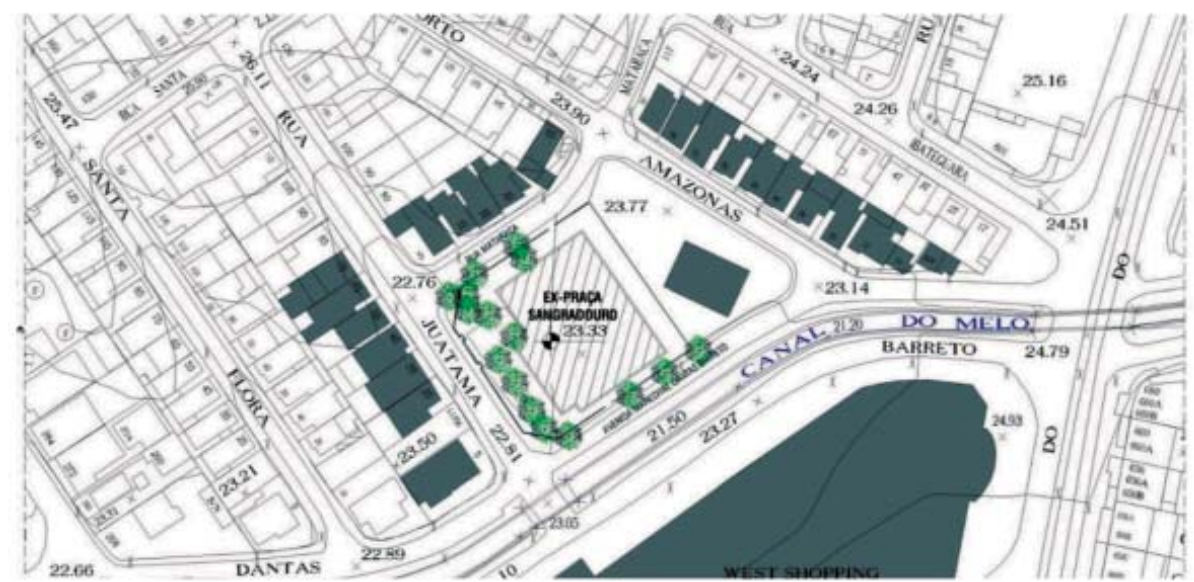

Fonte: Ana Paula Menezes sobre planta cadastral fornecida pela PCRJ, 2017 
d) Praça Marobá - Realengo

A comunidade conseguiu que a Praça Bom Conselho não fosse ocupada e a mudança se deu na ocupação de parte da mesma que já era destinada a outro tipo de equipamento. Nesse caso, a Praça Marobá não teve a mesma sorte, mas a força de sua comunidade se faz presente, pois essa foi a terceira opção de praça para a implantação da Clínica.

O Campo do Periquito, conforme é reconhecida até mesmo pelas ferramentas de busca (Google Maps), também possui campo oficializado, gradeado e iluminado por holofotes, porém seu estado de conservação beira o abandono. No entanto nos finais de semana o lugar é frequentado pelos moradores que organizam peladas regadas a churrasco e cervejas. O lugar também é dotado de vestiários como apoio às atividades ali realizadas.

A implantação da clínica, à direita na praça, não avançou para a área do campo justamente pela singularidade do mesmo ser cercado, ou seja, sua faixa de domínio é delimitada por elementos cujo atributo gera demonstração de territorialidade.

Figura 7: Implantação da Clínica Romulo Carlos Teixeira na Praça Marobá

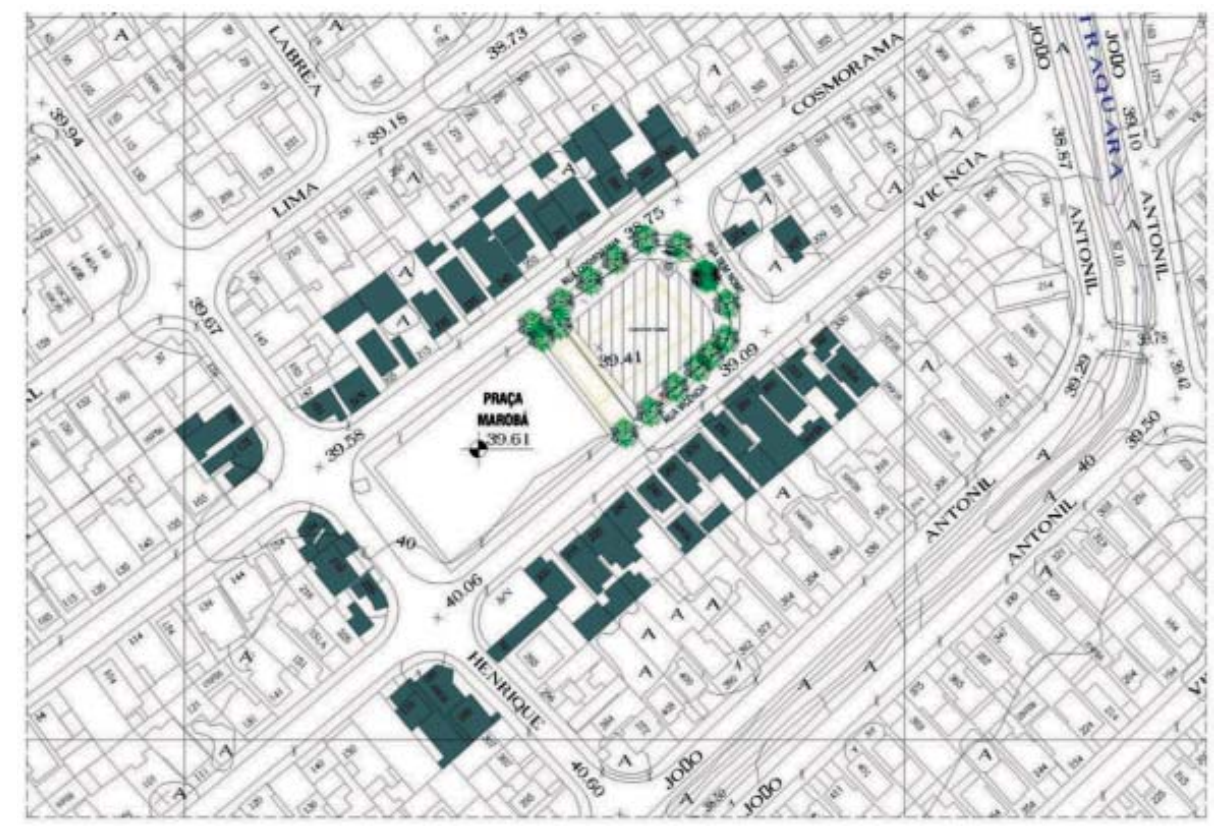

Fonte: Ana Paula Menezes sobre planta cadastral fornecida pela PCRJ, 2017

\section{Considerações finais}

Os projetos das clínicas e demais equipamentos públicos que ocuparam as áreas livres da cidade não levaram em consideração o estudo de impacto da sua implantação e as implicações na paisagem consolidada. Não é somente o elemento em si que causa o impacto negativo no seu entorno, mas também a forma descuidada com que esse elemento, que não deveria ter sido instalado naquele local, foi implantado, e por não levar em consideração especificidades socioculturais e biofísicas de cada local, desconsiderando qualquer forma de estruturação existente, já que uma praça é estruturada pelo seu entorno e é estruturante de uma determinada região. 
A cada dia a sociedade se vê mais distanciada das convivências sociais presenciais por meio de espaços livres públicos. A rua, a praça e o parque estão, a cada dia, mais perigosos, principalmente no Brasil, e essa insegurança acaba por aumentar o esvaziamento desses locais em um ciclo que parece não ter fim. Essa insegurança, segundo Jane Jacobs (2017), se dá justamente pela falta de uso, o que reforça esse ciclo. Desse esvaziamento surge a ocupação por equipamentos públicos, muitas vezes necessários e essenciais à vida do cidadão como saúde (Programa Saúde da Família com Clínicas da Família e Unidades de Pronto Atendimento), educação (Fábrica de Escolas do Amanhã) e segurança (Unidade de Ordem Pública), mas a que custo?

Santos e Vogel (1981) ressaltam que há importância na autonomia e na espontaneidade das apropriações dos espaços públicos frente às propostas de planejamento racionalista que mantém o espaço sob controle, legislando a respeito da sua apropriação. No entanto o que vem ocorrendo é justamente o contrário. A não ocupação dos espaços livres públicos acaba fomentando suas ocupações por edificações que controlam o ambiente do seu entorno. No caso da ocupação das praças por Clínicas da Família o entorno se torna um ponto polarizador que atrai moradores de outras áreas.

Dessa forma, a praça como local de convivência, palco de participações sociais e local democrático perde sua força ao não se inserir plenamente no cotidiano das pessoas e no tecido urbano da cidade. As praças, enquanto "elemento primário", atuam como agregadoras em um determinado perímetro urbano de uma determinada área.

Nas visitas aos locais de estudo de caso pudemos constatar que a população local anseia pela utilização das praças nos mesmos moldes das praças que encontramos nas pequenas cidades do interior do Estado. Presença de coretos, chafarizes, objetos de arte - tão difíceis de encontrar nas praças da zona oeste, porém comum nas praças do centro e zona sul da cidade, além de bancos, brinquedos, árvores frondosas. Enfim os moradores almejam qualidade de vida em forma de opções de lazer. Para estudar a apropriação das praças pelos moradores nas zonas norte e oeste, precisamos compreender:

- Como se dá a criação e efetivação de um espaço livre denominado praça e como se dá essa implantação?

- Em que momento se efetiva essa apropriação? Que processos produzem esses espaços?

- Por que questões da paisagem são negligenciadas?

- É necessário compreender como esse espaço livre público é produzido para se instrumentalizar o poder público a fim de que haja uma melhoria na qualidade dessas paisagens.

Após conclusão das pesquisas apresentadas nesse artigo, como desdobramento, pretende-se comparar o resultado obtido aos projetos existentes de equipamentos públicos de saúde e educação para as áreas reservadas para implantação de praças, problematizando a diminuição da incidência de espaços públicos, de vegetação e de usos voltados ao lazer. 


\section{Referências bibliográficas:}

ABREU, M. Evolução urbana do Rio de Janeiro. Rio de Janeiro: IPP Instituto Municipal de Urbanismo Pereira Passos, 1987.

BOBBIO, Norberto. Teoria da norma jurídica. 4. ed. Rio de Janeiro: Forense, 2006.

BRASIL. Lei Federal 6766 de 19/12/1979. Lei do Parcelamento do Solo Urbano. Brasília: Casa Civil, 1979.

CAMPOS, A. A.; QUEIROGA, E; GALENDER, F.; DEGREAS, H.; AKAMINE, R.; MACEDO, S. S.; CUSTÓDIO, V. (Orgs.). Sistemas de espaços livres-conceitos, conflitos e paisagens. São Paulo: FAUUSP, 2011.

Quadro dos sistemas de espaços livres nas cidades brasileiras. São Paulo: FAUUSP, 2012.

DWORKIN, Ronald. O império do direito. Tradução de Jefferson Luiz Camargo. 2 ed. São Paulo: Martins Fontes, 2007.

FILHO, R.F. e PEREIRA, F.R.C. A eficácia da função social na propriedade pública. In Universitas JUS, v. 27, n. 2, p. 43-56, 2016.

IBGE-Instituto Brasileiro de Geografia e Estatística/Ministério do Planejamento, Orçamento e Gestão. Censo Demográfico 2010. Rio de Janeiro: IBGE, 2011.

JACOBS, Jane. Morte e Vida de Grandes Cidades. São Paulo: Martins Fontes, 2017.

MACEDO et al. Considerações preliminares sobre o sistema de espaços livres e a constituição da esfera pública no Brasil. In TÂNGARI, SCHLEE, ANDRADE (org.) Sistema de espaços livres: o cotidiano, ausências e apropriações. Rio de Janeiro: FAU/UFRJ-PROARQ, 2009.

MAGNOLI, Miranda M. Espaços livres e urbanização: uma introdução a aspectos da paisagem metropolitana. Tese (Livre-Docência). São Paulo: FAUUSP, 1982.

PCRJ. Lei Orgânica do Município. - 2. ed. Rio de Janeiro: Centro de Estudos da Procuradoria-Geral do Município, 2010.

PEREZ, Mauricio D. Estado da Guanabara: Gestão e estrutura administrativa do Governo Carlos Lacerda. Tese (Doutorado). Rio de Janeiro: UFRJ/ IFCS, 2005.

QUEIROGA, E. F. A megalópole e a praça: o espaço entre a razão de dominação e a ação Comunicativa. Tese (Doutorado). São Paulo: FAUUSP, 2001.

SANTOS, Carlos Nelson F. dos; VOGEL, Arno (Coord.). Quando a rua vira casa: a apropriação de espaços de uso coletivo em um centro de bairro. Rio de Janeiro: IBAM/FINEP, 1981.

SILVA, Rooseman de Oliveira. O lugar do espaço público na paisagem pós-moderna. In Anais VII ENEPEA, Belo Horizonte, 2004.

SOUZA, Marcelo. Os conceitos fundamentais da pesquisa sócio-espacial. Rio de Janeiro: Bertrand, 2ed.,2015 
TÂNGARI, Vera. Um outro lado do Rio. Tese (Doutorado). São Paulo: FAUUSP, 1999.

. O papel dos espaços livres urbanos na conformação e definição de centralidades no município do Rio de Janeiro, In: Anais IV Seminário Internacional Academia de Escolas de Arquitectura e Urbanismo de Língua Portuguesa - A Língua que Habitamos. Belo Horizonte, UFMG/ AEAULP, 2017.

TÂNGARI et al. Morfologia urbana, suporte geo-biofísico e o sistema de espaços livres no Rio de Janeiro. In CAMPOS, A.A.; QUEIROGA, E.; GALENDER, F.; DEGREAS, H.; AKAMINE, R.; MACEDO, S.S.; CUSTÓDIO, V. (orgs.) Quadro dos sistemas de espaços livres nas cidades brasileiras. São Paulo: FAUUSP, 2012. p. 195-227.

WOLCH, Jennifer R. et al. (2014). Urban green space, public health and environmental justice: The challenge of making cities 'just green enough. In Landscape and Urban Planning, v. 125, 2014, p. 234-244. 